\title{
Partition and macronutrients accumulation in pineapple under nitrogen doses and plant density
}

\author{
Renata Patrícia Dias de Souza', Rodinei Facco Pegoraro2*, Sidnei Tavares dos Reis², \\ Victor Martins Maia', Regynaldo Arruda Sampaio²
}

\author{
IState University of Montes Claros, Janaúba, Brasil. \\ ${ }^{2}$ Federal University of Minas Gerais, Montes Claros, Brasil. \\ *Corresponding author, e-mail: rodinei_pegoraro@yahoo.com.br
}

\begin{abstract}
Studies related to the absorption and exportation capacity of macronutrients by irrigated pineapple are essential for the definition of adequate doses and fertilization management. The objective of this study was to evaluate the accumulation of biomass and macronutrients in the compartments (leaves, shoot, root, seedlings/slip, crown/top, and fruit) of 'Vitória' pineapple irrigated in the semiarid region after the use of nitrogen doses and population densities. The treatments, arranged in randomized blocks with three replicates, arranged in a $5 \times 4$ factorial scheme, consisted of five nitrogen doses $(0,5,10,15$ and $20 \mathrm{~g}$ per plant) and four population densities $(51,282,76,923,90,909$, and 126,984 plants ha-1). The accumulation of biomass and macronutrients in the pineapple compartments was evaluated at the end of the growing cycle. The increase of $\mathrm{N}$ doses combined with the increase of the plant population promoted a linear increase in the accumulation of biomass and macronutrients by the pineapple plants. The leaves presented greater accumulation of macronutrients, followed by the seedlings, shoot, fruit, crown, and roots. The pineapple presented the following decreasing order of macronutrient absorption: $\mathrm{K}>\mathrm{N}>\mathrm{Ca}>\mathrm{P}>\mathrm{Mg}>\mathrm{S}$. At the dose of $20 \mathrm{~g}$ per plant of $\mathrm{N}$ and population of 126,984 plants $^{-1}$ were exported from the area by fruits, 1,311 (12\%), 150 (9\%), $144(11 \%), 52(11 \%), 46(12 \%)$ and 36 (12\%) kg ha-1 of K, N, Ca, P, Mg, and S, respectively; and by the shoots, 2,426 (22\%), 480 (29\%), $147(11 \%), 101(21 \%), 67(18 \%)$, and $45(15 \%) \mathrm{kg} \mathrm{ha}^{-1}$ of $\mathrm{K}, \mathrm{N}, \mathrm{Ca}, \mathrm{P}, \mathrm{Mg}$, and S, respectively.
\end{abstract}

Keywords: Ananas comosus var. comosus, nutrient content, nutrients exportation

\section{Introduction}

The pineapple (Ananas comusus var. comosus L. Merril.) is a bromeliad that adapts well to semi-arid conditions (Franco et al., 2014). Also, the adoption of a fertilization program suited to the local conditions of cultivation is essential, because Brazilian soils do not supply the nutritional demand of pineapple plants (Guarocon \& Ventura, 2011; Cardoso et al., 2013; Pegoraro et al. 2014a).

Nitrogen is the macronutrient which provides more significant increases in the vegetative development and the productivity of the pineapple. This nutrient is one of many compounds which are essential to the processes of plant growth, such as amino acids and proteins (Marques et al., 2011; Caetano et al., 2013; Taiz \& Zeiger, 2013), also promotes an increase in the absorption of macronutrients, and exerts considerable influence on fruit weight (Cardoso et al., 2013).

Another factor that interferes with the absorption and accumulation of nutrients is the population density. Scientific studies indicated an increase in the productivity and the macronutrient absorption with the rise in the population density of pineapple trees (Santana et al., 2001; Silva et al., 2009; Cardoso et al., 2013).

The increase of the plant population magnifies the competition for light, water, and 
nutrients. This competition may change the plant growth pattern and fruit weight (Guarçoni M. \& Ventura, 2011). For the Smooth Cayenne and Gold varieties, every 10,000 plants ha ${ }^{-1}$ added to the stand mean fruit weight decreases 102 and $106 \mathrm{~g}$, and productivity increases by 8.27 and $16 \dagger$ ha $^{-1}$, respectively (Santana et al., 2001).

Despite the notable interference of nitrogen fertilization and population density in plant growth, productivity, and nutrient absorption patterns, that information on the accumulation and exportation of biomass and nutrients in the pineapple compartments is scarce, especially when grown under irrigated systems in the semiarid. This information can be considered essential for the elaboration of future fertilization management programs. Given the above, the objective was to evaluate the accumulation of biomass and macronutrients in the compartments of irrigated pineapple in the semi-arid conditions, after the use of nitrogen doses and population densities.

\section{Materials and Methods}

The study was carried out in a Red Latosol in the north of Minas Gerais, located at $15^{\circ} 43^{\prime} 47.4^{\prime \prime} \mathrm{S}$ and $43^{\circ} 19^{\prime} 22.1^{\prime \prime} \mathrm{W}$, with an elevation of $533 \mathrm{~m}$. The climate of the region is of type "Aw" (tropical hot showing cold and dry winter) according to the classification of Köppen. The average rainfall is approximately $870 \mathrm{~mm}$ year $^{-1}$, distributed irregularly, with rainy season concentrated from October to March. The physical and chemical attributes of the soil in the 0-0.20 m layer and before the pineapple plantation showed the following characteristics: 27; 9 and $64 \mathrm{dag} \mathrm{kg}^{-1}$ of clay, silt and sand, respectively; 0.9 dag $\mathrm{kg}^{-1}$ of organic matter; $\mathrm{pH}$ $\left(\mathrm{H}_{2} \mathrm{O}\right) 5.40 ; 3.70 \mathrm{mg} \mathrm{dm}^{-3}$ of P (Mehlich 1); 72.00 $\mathrm{mg} \mathrm{dm}^{-3}$ of $\mathrm{K}$ (Mehlich 1); $1.30 \mathrm{cmol}_{\mathrm{c}} \mathrm{dm}^{-3}$ of Ca; $0.50 \mathrm{cmol} / \mathrm{dm}^{-3}$ of $\mathrm{Mg} ; 0.26 \mathrm{cmol}_{\mathrm{c}} \mathrm{dm}^{-3}$ of $\mathrm{Al}$ and $1.80 \mathrm{cmol}_{\mathrm{c}} \mathrm{dm}^{-3}$ of $\mathrm{H}+\mathrm{Al}$.

Soil preparation consisted of harrowing and ridging. The planting was carried out with micro-propagated 'Vitória' pineapple seedlings, previously selected by height (between 10 and $15 \mathrm{~cm}$ ), to maintain homogeneity within the experimental blocks.

To supply the pineapple with $\mathrm{Ca}$ and
Mg, $500 \mathrm{~kg} \mathrm{ha}^{-1}$ of dolomitic limestone with $80 \%$ PRNT was applied to the soil using harrowing. The $P$ and $K$ doses corresponded respectively to 3 and $15 \mathrm{~g}$ per plant, in the single superphosphate and potassium chloride sources. Phosphorus was applied in the planting groove, and $\mathrm{N}$ and $\mathrm{K}$ coverage fertilizations were divided every two months, totaling six applications (10\%, 10\%, $20 \%, 20 \%, 20 \%$ and $20 \%$ of the recommended dose) in the vegetative period. Fertilizers were applied manually, on the soil surface and near the planting line of the pineapples. Foliar micronutrients were fed with boric acid $(0.07 \%)$, zinc sulfate $(0.1 \%)$ and copper sulfate $(0.1 \%)$ in the months corresponding to soil fertilization with $\mathrm{N}$ and $\mathrm{K}$ and soil acidity correction followed the recommendation of Souza et al. (1999).

Fixed conventional sprinkler irrigation was maintained throughout the crop cycle, using sprinklers with a flow rate of $500 \mathrm{~L} \mathrm{~h}^{-1}$. Plants were watered three times a week. Irrigation time varied according to the development stage of the plants. The floral induction was performed 600 days after planting by applying, at the center of the leaf rosette, about $50 \mathrm{~mL}$ per plant of the

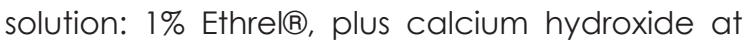
the dose of $0.35 \mathrm{~g}$ per liter of water.

The accumulations of dry biomass and macronutrients in the compartments of the plants were evaluated at the end of the crop cycle. The plants were sampled when the fruits reached the ideal maturation point for harvest (at least 50\% of the bark with yellow coloration) and then sent to the laboratory where they were divided into compartments: leaves, shoot, roots, seedlings, crown and uncrowned fruit. These samples were sanitized by washing in distilled water and dried in a forced air circulation oven at $65^{\circ} \mathrm{C}$ until constant weight, weighed for determination of biomass accumulation, ground in a Willey mill (2 $\mathrm{mm}$ sieves) and analyzed the nutritional contents. The total $\mathrm{N}$ contents were determined by the Kjeldahl method (sulfuric digestion) (Bataglia et al., 1983). P, K, S, Ca and Mg were extracted by nitro-perchloric digestion and determined according to Silva (2009).

The accumulation of nutrients in the compartments of the plants $\left(\mathrm{kg} \mathrm{ha}^{-1}\right)$ was obtained by multiplying their content by the production of 
dry biomass per hectare. The accumulation of total biomass corresponded to the biomass sum of the compartments. The accumulations in the remaining biomass were obtained by the sum of the results of all compartments except fruit and crown. Macronutrients accumulated in the offspring (seedling and offspring) and fruits (fruit and crown) were exported from the growing area.

The results were analyzed with the variance. Since the F test was necessary for the interaction between the dose and population density, a regression analysis of the response methodology to the medium SELECTION = STEPWISE was performed on the MODEL GLM procedure command line of the software SAS so that the selection of models is corrected between the tested models (linear, quadratic and cubic). Significance was accepted for the entry and permanence of the parameters in the model of $15 \%$ maximum.

\section{Results and Discussion}

The variance analysis of the results indicated the existence of significant interaction
( $p<0.001$ ) between $\mathrm{N}$ doses and population densities for all analyzed characteristics. The maximum accumulation of total biomass, remaining in the compartments of the plant, except for the root, occurred with the use of 20 $g$ per plant of $\mathrm{N}$ and a population of 126,984 plants ha-1 (Figure 1 and Table 1). The maximum accumulations of total and remaining biomass were 322.26 and $286.43 \mathrm{tha}^{-1}$, respectively; being these stocks $70 \%$ higher than that obtained in the treatment with the absence of nitrogen fertilization in 51,282 plants ha ${ }^{-1}$.

The maximum biomass stocks in the leaves and stem were equivalent to 188.00 and $270.56+\mathrm{ha}^{-1}$, respectively. In the roots, the maximum accumulation of biomass occurred in the absence of nitrogen fertilization added to the most abundant plant population, and corresponded to $2.92+\mathrm{ha}^{-1}$. The increase of $\mathrm{N}$ doses, up to $20 \mathrm{~g}$ per plant, led to a reduction of $18.2 \%$ of the root biomass, indicating that the higher availability of nitrogen in the soil from the fertilization implied a larger partition of photoassimilates for the production of biomass in the aerial part to the detriment of the root system.
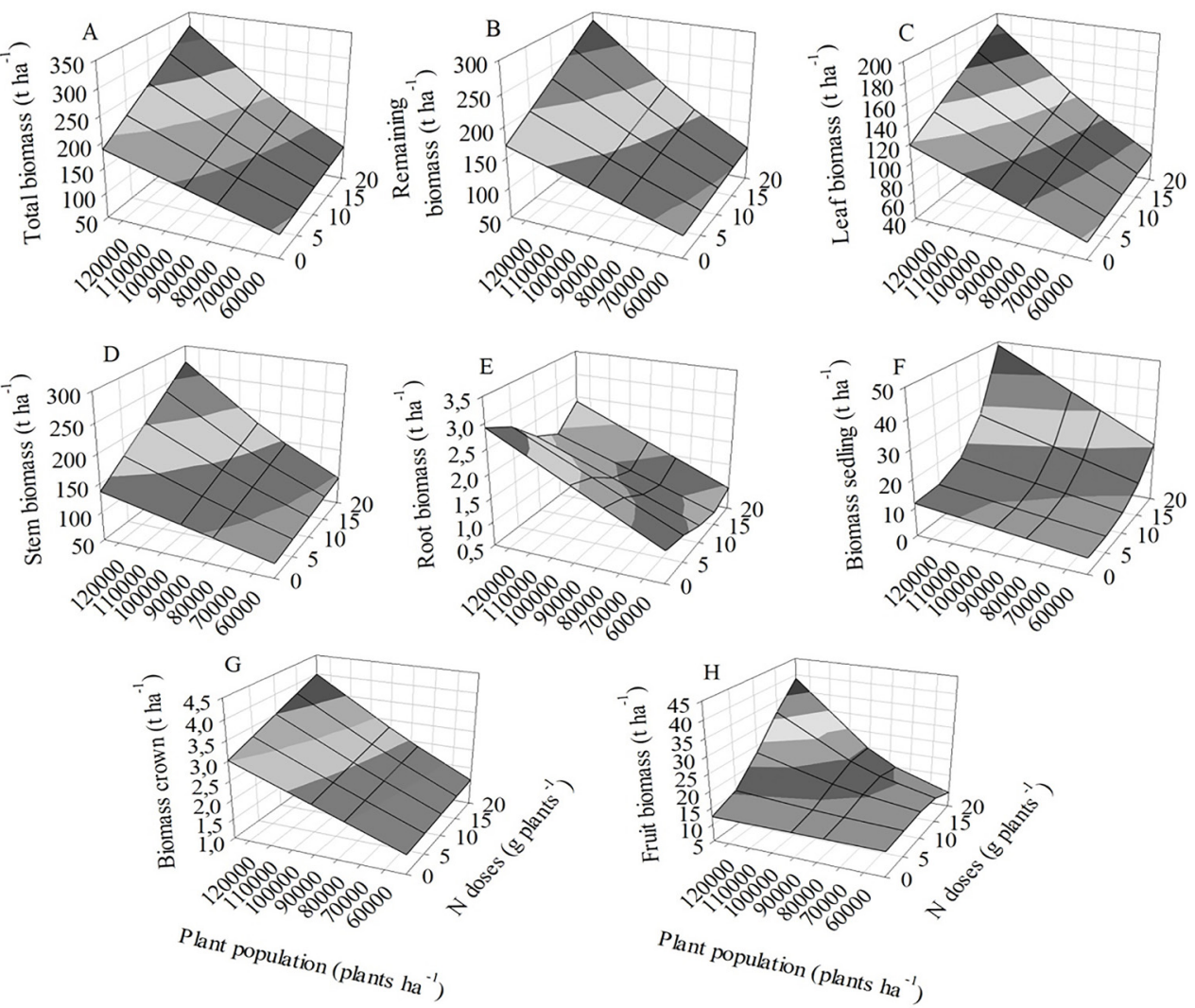

Figure 1 Accumulation of total dry biomass (A), remainings (B), leaf (C), stem (D), root (E), seedling (F), crown $(\mathrm{G})$ and fruit $(\mathrm{H})$ of pineapple 'Vitória' as a function of $\mathrm{N}$ doses and population densities. 
Table 1. Equations and determination coefficients related to the accumulation of total biomass, remaining biomass (Rem.), Leaf, stem, root, offspring, crown, and fruit of pineapple.

\begin{tabular}{|c|c|c|}
\hline Variable & Equation & $\mathrm{R}^{2}$ \\
\hline Total & $\hat{Y}=34.66+0.00124 D+0.000000000419284\left(N^{2}\right)$ & 0.73 \\
\hline Rem. & $\begin{array}{l}\hat{Y}=211.97-131.76 N+0.038 D+50.99 N^{2}-0.00000026 D^{2}-1.7925 N^{3}+0.000000041\left(N D^{2}\right)-0.00087 \\
\left(N^{2} D\right)+0.000035\left(N^{3} D\right)-0.000000000049\left(N^{3} D^{2}\right)\end{array}$ & 0.70 \\
\hline Leaf & $\begin{array}{l}\hat{Y}=532.77+0.017 D+9.29 N^{2}-0.00000013 D^{2}-0.26 N^{3}-0.0019(N D)+0.000000036 \\
\left(N D^{2}\right)-0.0000000030\left(N^{2} D^{2}\right)+0.000000000089\left(N^{3} D^{2}\right)\end{array}$ & 0.52 \\
\hline Stem & $\begin{array}{l}\hat{Y}=456.12-82.44 N+20.4036 N^{2}-0.000000014 D^{2}-0.74 N^{3}+0.000000012\left(N^{2}\right)-0.00027 \\
\left(N^{2} D\right)+0.000012\left(N^{3} D\right)-0.000000000021\left(N^{3} D^{2}\right)\end{array}$ & 0.72 \\
\hline Root & $\begin{array}{l}\hat{Y}=15.25+0.00018 D+0.025 \mathrm{~N}^{2}-0.0000000013 \mathrm{D}^{2}+0.00000000022\left(\mathrm{ND}^{2}\right)-0.0000033 \\
\left(\mathrm{~N}^{2} \mathrm{D}\right)-0.0000000000063\left(\mathrm{~N}^{2} \mathrm{D}^{2}\right)+0.00000013\left(\mathrm{~N}^{3 *} \mathrm{D}\right)\end{array}$ & 0.60 \\
\hline Seedling & $\hat{\mathrm{Y}}=49.72+0.055 \mathrm{~N}^{3}+0.00057(\mathrm{ND})-0.000074\left(\mathrm{~N}^{2 *} \mathrm{D}\right)+0.000002\left(\mathrm{~N}^{3 *} \mathrm{D}\right)$ & 0.81 \\
\hline Crown & $\hat{Y}=23.38+0.58 \mathrm{~N}-0.00000000017 D^{2}-0.0023 \mathrm{~N}^{3}-0.00001(\mathrm{ND})+0.0000009\left(\mathrm{~N}^{2} \mathrm{D}\right)$ & 0.70 \\
\hline Fruit & $\hat{Y}=57.64+14.29 \mathrm{~N}+0.0033 \mathrm{D}-2.43 \mathrm{~N}^{2}-0.000000021 \mathrm{D}^{2}+0.095 \mathrm{~N}^{3}$ & 0.74 \\
\hline
\end{tabular}

In the treatments with the highest $\mathrm{N}$ dose (20 g per plant) and population density $(126,984$ plants $\mathrm{ha}^{-1}$ ), $42.83 \mathrm{tha}^{-1}$ of dry fruit biomass (with crown) and $48.80 \mathrm{tha}^{-1}$ of dry biomass of seedlings, which together corresponded to $28.43 \%$ of the total biomass produced by pineapple. The harvest index for the dose of $20 \mathrm{~g}$ per plant and 126,984 plants $\mathrm{ha}^{-1}$ was $13.3 \%$, considering the dry matter. Thisresult of the harvest index illustrates that $13.3 \%$ of the biomass produced by the plant was allocated for fruit production. Vilela et al. (2015) reported a harvest rate of $20 \%$ for "Vitória" pineapple, but the calculation was made from the fresh matter of the plant and fruits.

Effect of nitrogen fertilization on the increase of biomass production was observed by Silva et al. (2012), indicating the increase of $0.018 \mathrm{~g}$ in the weight of leaf ' $\mathrm{D}$ ' for each $\mathrm{kg} \mathrm{ha}^{-1}$ of $\mathrm{N}$ added. Cardoso et al. (2013) also reported an increase of $0.82 \mathrm{~g}$ in the weight of leaf ' $\mathrm{D}$ ', and $12.74 \mathrm{~g}$ in the weight of the fruit with crown, per $\mathrm{g}$ (per plant) of $\mathrm{N}$ added.

The increase in planting density studied by Santana et al. (2001) provided an increase in the biomass production of the fruits, producing 103.82 t ha-1 $^{-1}$ of fresh biomass using 87,791 plants $\mathrm{ha}^{-1}$ for "Smooth Cayenne". The densification in the 'Vitória' pineapple plantation, reported by Cardoso et al. (2013), reduced the number of leaves emitted but did not interfere in the weight of the fruits. Indicating that the densification represents a possible management strategy to increase fruit biomass production by area.
The use of $20 \mathrm{~g}$ per plant of $\mathrm{N}$ associated with the most abundant plant population increased the accumulation of $\mathrm{N}$ in the total biomass, remaining and in most of the compartments of the pineapple, except for that obtained in the leaves and roots (Figure 2 and Table 2). The maximum accumulation of $\mathrm{N}$ in total and remaining biomass was 1,665.41 and $1,527.74 \mathrm{~kg} \mathrm{ha}^{-1}$, respectively, in the largest plant population and $\mathrm{N}$ dose. The stem accumulated $304.90 \mathrm{~kg} \mathrm{ha}^{-1}$ of $\mathrm{N}$. higher accumulation of $\mathrm{N}$ in the leaves was $1,093.81 \mathrm{~kg} \mathrm{ha}^{-1}$ with the addition of $5 \mathrm{~g}$ per plant of $\mathrm{N}$ in the most abundant plant population.

The seedlings, the crown and the fruit accumulated $479.77 ; 30.67$ and $118.88 \mathrm{~kg} \mathrm{ha}^{-1}$ of $N$, respectively, in the population of 126,984 plants $\mathrm{ha}^{-1}$ and dose of $20 \mathrm{~g}$ of $\mathrm{N}$ per plant (Table 2). In this regard, $149.55 \mathrm{~kg} \mathrm{ha}^{-1}$ of $\mathrm{N}$ were exported by the fruits and $479.77 \mathrm{~kg} \mathrm{ha}^{-1}$ of $\mathrm{N}$ by the seedlings, therefore corresponding to $37.79 \%$ of the total $\mathrm{N}$ accumulated. On the other hand, $62.21 \%\left(1,036.09 \mathrm{~kg} \mathrm{ha}^{-1}\right.$ of $\left.\mathrm{N}\right)$ remained in the growing area. This $\mathrm{N}$ stored in the compartments of the plant may be mineralized in the soil after its decomposition, contributing to the economy in the fertilization of subsequent crops.

In the roots, the accumulation of all macronutrients was higher in the lower $\mathrm{N}$ doses along with the highest population density and corresponded to $10.11 \mathrm{~kg} \mathrm{ha}^{-1}$ of $\mathrm{N} ; 23.44 \mathrm{~kg}$ $\mathrm{ha}^{-1}$ of $\mathrm{K} ; 9.25 \mathrm{~kg} \mathrm{ha}^{-1}$ of $\mathrm{Ca} ; 1.18 \mathrm{~kg} \mathrm{ha}^{-1}$ of $\mathrm{Mg}$; $2.28 \mathrm{~kg} \mathrm{ha}^{-1}$ of $\mathrm{S}$ and $1.13 \mathrm{~kg} \mathrm{ha}^{-1}$ of $\mathrm{P}$ (Tables 2, 
$3,4,5,6$ and 7). In this sense, a reduction in the macronutrient accumulation in the roots was obtained with the increase of $N$ doses, justified by the lower root production. Taiz \& Zeiger (2013) described that the abundant supply of nutrients and water to the plant provides energy savings in root production since a relatively small root system can supply the nutritional demand of the whole plant.
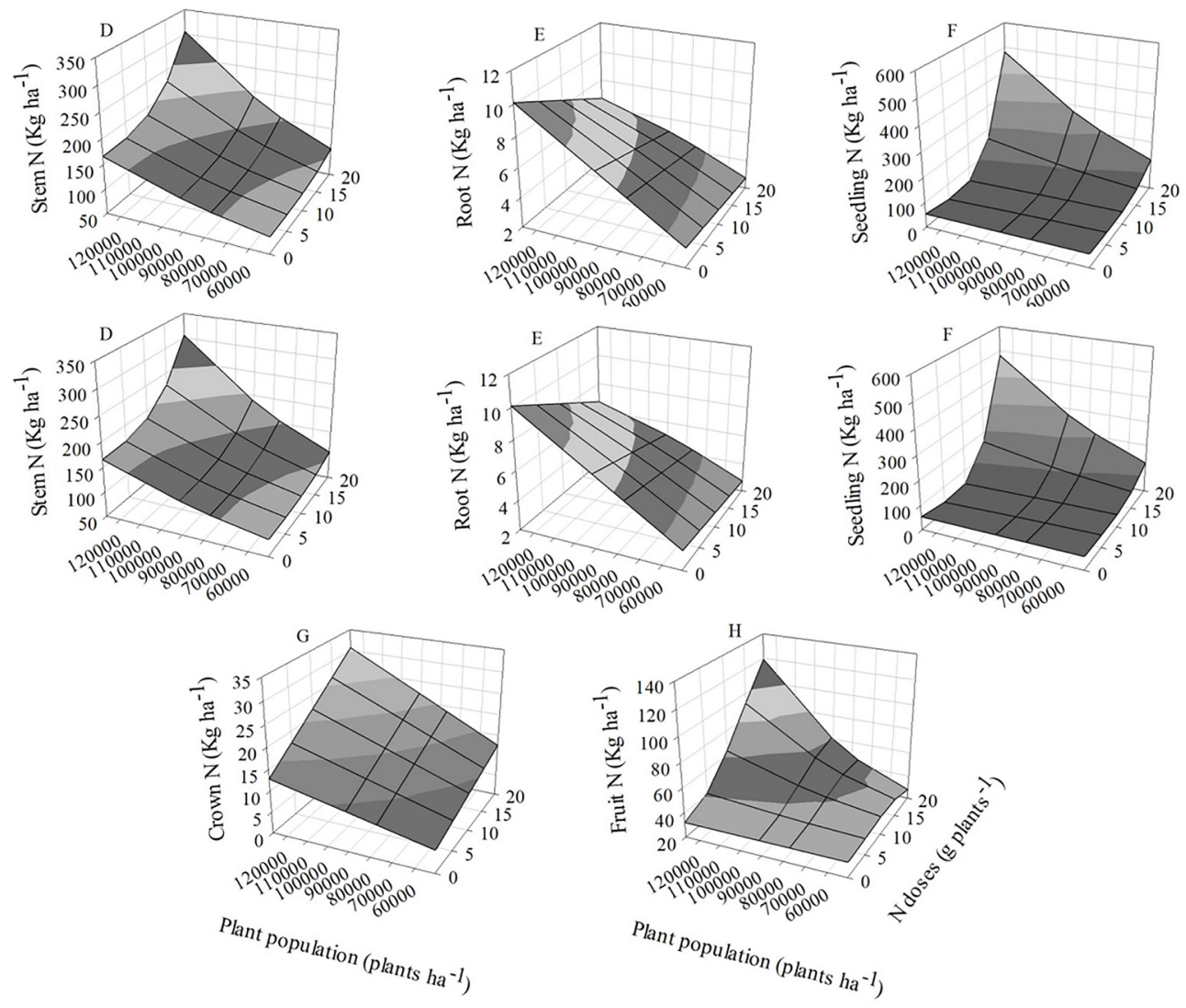

Figure 2. Accumulation of total $N(A)$, in the remaining biomass $(B)$, leaf $(C)$, stem $(D)$, root $(E)$, seedling $(F)$, crown $(\mathrm{G})$ and fruit $(\mathrm{H})$ of pineapple 'Vitória' as a function of $\mathrm{N}$ doses and population densities.

Table 2. Equations and determination coefficients for the total $\mathrm{N}$ accumulation in the remaining biomass (N Rem.), Leaf, stem, root, seedling, crown and fruit of the pineapple.

\begin{tabular}{clc}
\hline Variable Equation & $R^{2}$ \\
\hline Total & $\hat{Y}=453.21+0.000000034\left(N^{*} D^{2}\right)-0.0000000040\left(N^{2} * D^{2}\right)+0.00000000013\left(N^{3} D^{2}\right)$ & 0.91 \\
Rem. & $\hat{Y}=415.24+0.000000033\left(N D^{2}\right)-0.0000000039\left(N^{2} D^{2}\right)+0.00000000013\left(N^{3} D^{2}\right)$ & 0.91 \\
Leaf & $\hat{Y}=274.06+0.000000027\left(N D^{2}\right)-0.0000000030\left(N^{2} D^{2}\right)+0.000000000097\left(N^{3} D^{2}\right)$ & 0.88 \\
Stem $\quad \hat{Y}=76.82+0.0000000031 D^{2}+0.0000000028\left(N D^{2}\right)-0.00000000037\left(N^{2} D^{2}\right)$ & 0.79 \\
$\quad+0.000000000013\left(N^{3} D^{2}\right)$ & 0.85 \\
Root $\quad \hat{Y}=-1.79+0.00011 D-0.0000000000070\left(N^{2} D^{2}\right)+0.00000000000032\left(N^{3} D^{2}\right)$ & 0.85 \\
Seedling $\hat{Y}=18.05+0.00040(N D)-0.000053\left(N^{2} D\right)+0.0000020\left(N^{3} D\right)$ & 0.80 \\
Crown $\quad \hat{Y}=1.51+1.26 N+0.00015 D-0.13 N^{2}+0.0031 N^{3}$ & 0.81 \\
Fruit $\quad \hat{Y}=-56.35+0.0020 D-0.0000000090 D^{2}+0.000000026(N 3)$ &
\end{tabular}

The highest accumulations of $P$ in the remaining biomass, remaining, seedling, crown, and fruit of the pineapple occurred after fertilization with $20 \mathrm{~g}$ per plant of $\mathrm{N}$ and higher population density, but the increase of $\mathrm{N}$ doses reduced $P$ accumulation in the leaves (Figure 3 and Table 3 ). This reduction in the $P$ stocks in the leaves may have occurred because the 
pineapple absorbed $\mathrm{P}$ by root trapping, and in the higher $\mathrm{N}$ dose there was less root production, leading to a decrease in the $\mathrm{P}$ allocation in the leaves at the end of the cycle, since at this stage the nutrients are translocated to the reproductive parts. Guarçoni M. \& Ventura (2011) also observed a decrease in the P foliar contents with $\mathrm{N}$ rates increased in the Jupi and MD-2 varieties.
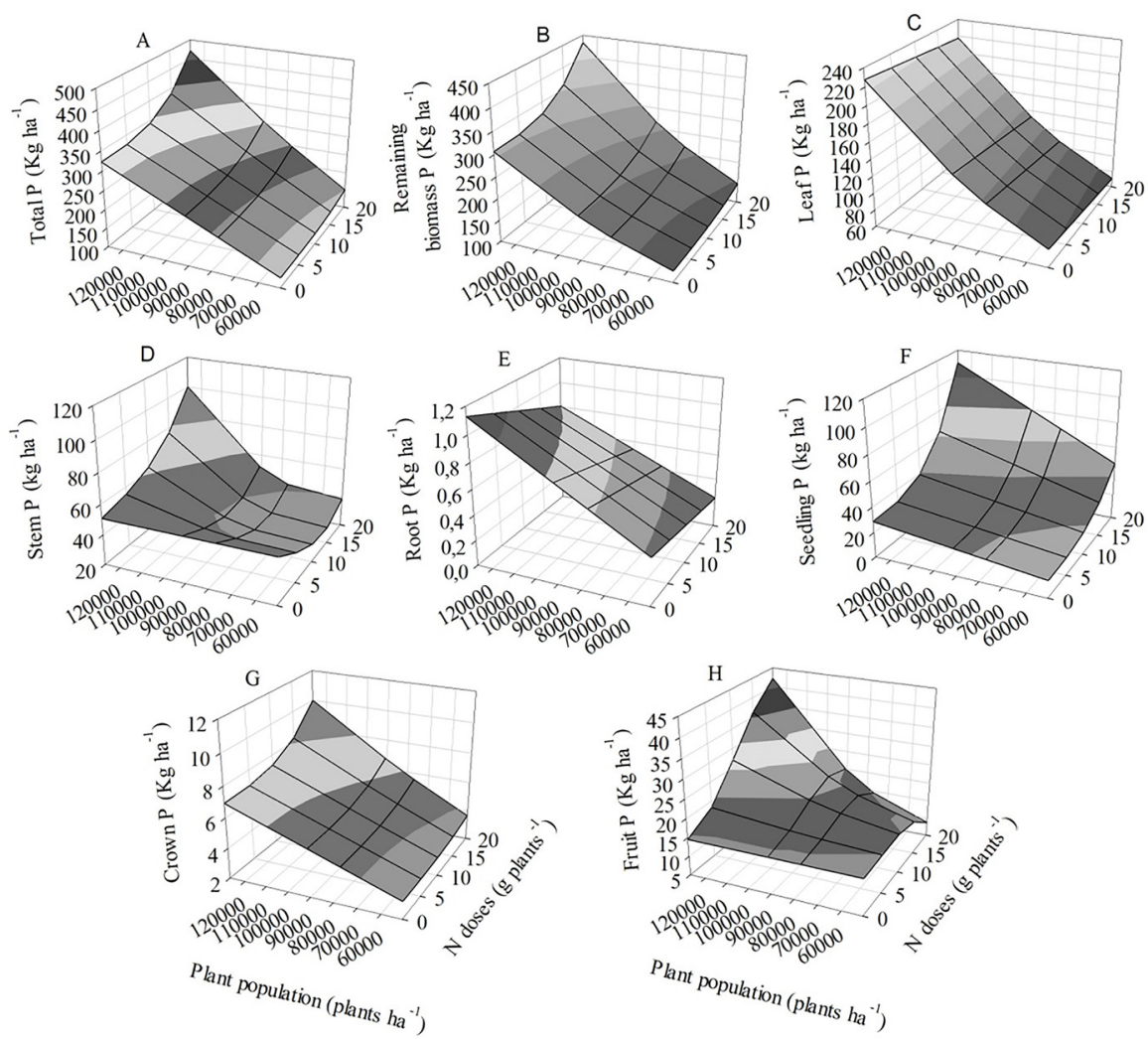

Figure 3. Total $P$ accumulations (A), remaining biomass (B), leaf (C), stem (D), root (E), seedling (F), crown $(G)$ and fruit $(H)$ of pineapple 'Vitória' as a function of $\mathrm{N}$ doses and population densities.

Table 3. Equations and determination coefficients related to the accumulation of total $P$ in the remaining biomass (Rem.), Leaf, stem, root, seedling, crown and fruit of the pineapple.

\begin{tabular}{clc}
\hline Variable Equation & $R^{2}$ \\
\hline Total & $\hat{Y}=36.2+0.002 D+0.000000006\left(N D^{2}\right)-0.0000000008\left(N^{2} D^{2}\right)+0.00000000003\left(N^{3} D^{2}\right)$ & 0.88 \\
Rem. & $\hat{Y}=33.8+0.002 D+0.000000005\left(N D^{2}\right)-0.0000000007\left(N^{2} D^{2}\right)+0.00000000002\left(N^{3} D^{2}\right)$ & 0.88 \\
Leaf & $\hat{Y}=0.8+0.001 D+0.000000003\left(N D^{2}\right)-0.0000000005\left(N^{2} D^{2}\right)+0.00000000002\left(N^{3} D^{2}\right)$ & 0.87 \\
Stem $\quad \hat{Y}=13.56+0.00040 D+0.0095 N^{3}-0.0000050\left(N^{2} D\right)+0.000000000030\left(N^{2} D^{2}\right)$ & 0.72 \\
Root $\hat{Y}=-0.13+0.000010 D-0.00000020(N D)$ & 0.80 \\
Seedling $\hat{Y}=7.81+0.00014(N D)-0.000020(N 2)+0.00000070\left(N^{3} D\right)$ & 0.79 \\
Crown $\hat{Y}=0.49+0.000050 D+0.000000000000020\left(N^{3} D^{2}\right)$ & 0.78 \\
Fruit $\hat{Y}=-17.53+0.00070 D-0.0000000020 D^{2}-0.0000010\left(N^{2} D\right)+0.000000060\left(N^{3} D\right)$ & 0.71 \\
\hline In the equation: $N=$ doses of $N$ and $D=$ density of plants; $R 2=$ determination coefficient.
\end{tabular}

The maximum accumulation of $P$ in the total biomass and the remaining biomass corresponded to 470.44 and $432.19 \mathrm{~kg} \mathrm{ha}^{-1}$, respectively (Table 3 ). The leaves and stem stocked respectively, 227.64 and $100.03 \mathrm{~kg}$ $\mathrm{ha}^{-1}$ of $\mathrm{P}$. In the seedlings, crown, and fruit, the accumulation of $\mathrm{P}$ corresponded to 100.85; 9.99 and $42.17 \mathrm{~kg} \mathrm{ha}^{-1}$, respectively. $100.85 \mathrm{~kg} \mathrm{ha}^{-1}$ and $52.16 \mathrm{~kg} \mathrm{ha}^{-1}$ of $\mathrm{P}$ were exported by the seedlings and fruits, respectively, corresponding to $32.58 \%$ and remaining in the area $67.42 \%(317.43 \mathrm{~kg} \mathrm{ha}$ 1) of $\mathrm{P}$ accumulated in the total biomass, in the largest population of plants and $20 \mathrm{~g}$ per plant of $\mathrm{N}$.

The maximum accumulations of $K$ observed in the compartments of the pineapple, except the roots, occurred when the highest $\mathrm{N}$ dose combined with the largest adopted plant population (Figure 4 and Table 4). The accumulation of total $K$ and the remaining 
biomass was 10,958.26 and 9,732.08 $\mathrm{kg} \mathrm{ha}^{-1}$, respectively. In the leaves and in the stem were accumulated $6,099.77$ and $1,052.60 \mathrm{~kg} \mathrm{ha}^{-1}$.
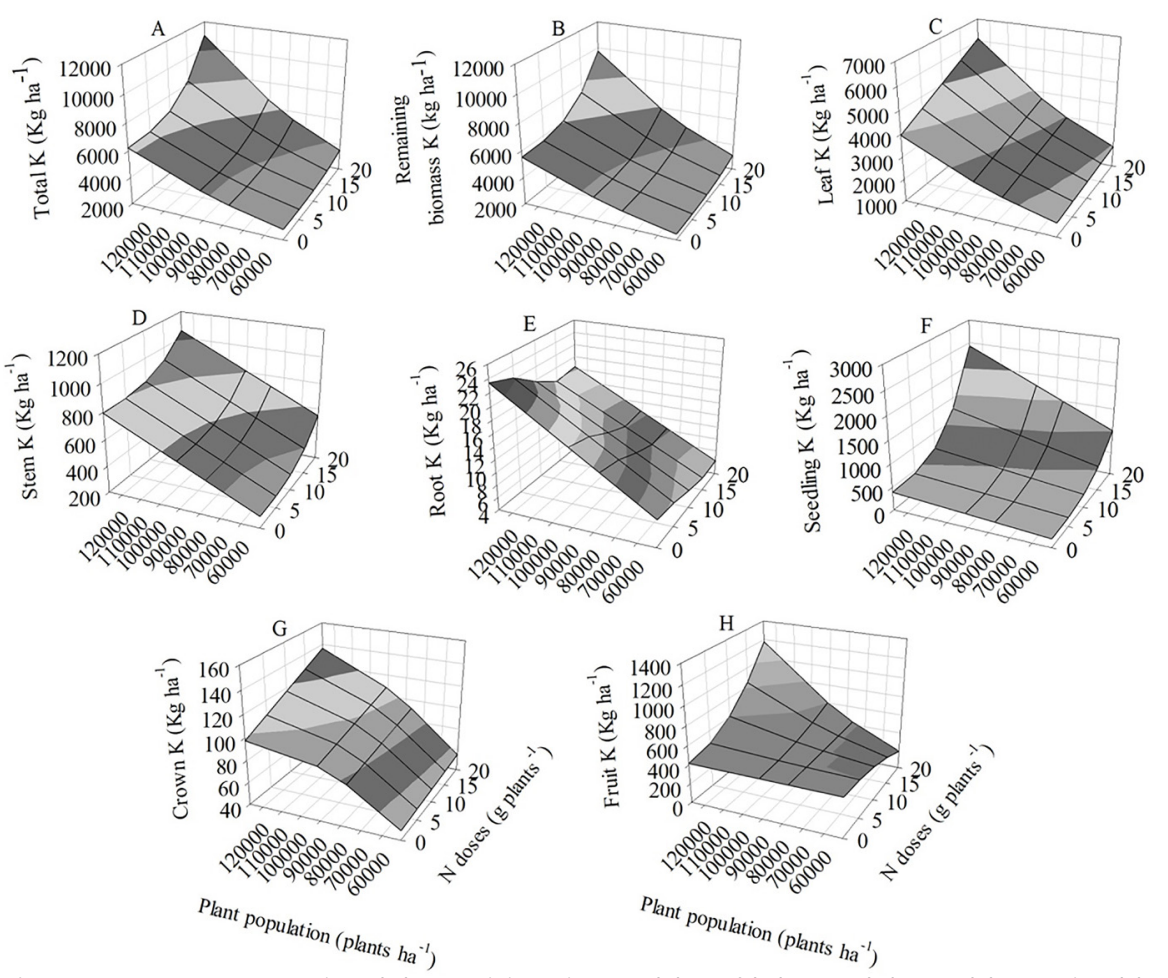

Figure 4. Total $K$ accumulations (A), remaining biomass (B), leaf (C), stem (D), root (E), seedling (F), crown $(G)$ and fruit $(H)$ of pineapple 'Vitória' as a function of $\mathrm{N}$ doses and population densities.

Tabela 4. Equations and determination coefficients related to the accumulation of total $\mathrm{K}$ in the remaining biomass (Rem.), Leaf, stem, root, seedling, crown and fruit of the pineapple.

\begin{tabular}{|c|c|c|}
\hline Variable & Equation & $\mathrm{R}^{2}$ \\
\hline Total & $\hat{Y}=1702.60+0.0000002 D^{2}+0.000000007\left(N^{2}\right)$ & 0.80 \\
\hline Rem. & $\hat{Y}=1409.92+0.0000002 D^{2}+0.000000007\left(N^{2}\right)$ & 0.81 \\
\hline Leaf & $\hat{Y}=1087.40+0.0000002 D^{2}+0.000000006\left(N^{2}\right)$ & 0.82 \\
\hline Stem & $\hat{Y}=-782.94+0.025 D-0.0000001 D^{2}+0.13 N^{3}+0.000000005\left(N^{*} D^{2}\right)-0.00004\left(N^{2} D\right)$ & 0.72 \\
\hline Root & $\hat{Y}=0.91+0.00009 D+0.0012 N^{3}+0.00000000004\left(N^{2}\right)-0.0000007\left(N^{2} D\right)+0.0000000000001\left(N^{3} D^{2}\right)$ & 0.66 \\
\hline Seedling & $\hat{Y}=0.42+0.0013 N^{3}-0.0000001\left(N^{2} D\right)$ & 0.79 \\
\hline Crown & $\hat{Y}=15.76+0.0006 \mathrm{D}+0.0000000002\left(\mathrm{ND}^{2}\right)$ & 0.82 \\
\hline Fruit & $\hat{Y}=338.90+0.0151 \mathrm{D}-0.0000000 D^{2}+0.000000007\left(N^{2}\right)-0.000000001\left(N^{2} D^{2}\right)+0.00000000004\left(N^{3} D^{2}\right)$ & 0.75 \\
\hline
\end{tabular}

The seedlings, the crown and the fruit accumulated, respectively, 2,425.79; 136,35 and $1,175,03 \mathrm{~kg} \mathrm{ha}^{-1}$ of $\mathrm{K}$. In the reproductive components of pineapple, with the use of maximum doses of $\mathrm{N}$ and population densities, the export of $1,311.38 \mathrm{~kg} \mathrm{ha}^{-1}$ of $\mathrm{K}$ by fruits and $2.425,79 \mathrm{~kg} \mathrm{ha}^{-1}$ by the seedlings $(34.1 \%$ of total accumulated $\mathrm{K}$ ) and $7,221.09 \mathrm{~kg} \mathrm{ha}^{-1}$ of $\mathrm{K}(65.9 \%$ of accumulated total) remained in the growing area. As a nutrient that is found as a free ion in the cells (Taiz \& Zaiger, 2013), K accumulated in plant residues will be made available to the plants of the next crop in a shorter period than the other nutrients. In this sense, there is a possibility that, from the second pineapple cultivation cycle, the recommendation of potassium fertilization will decrease due to nutrient cycling in the cultural remains of the first cycle (Silva et al., 2009).

The accumulations of $\mathrm{Ca}$ in most of the pineapple compartments increased with increasing N rates and population densities (Figure 5 and Table 5). The maximum accumulations corresponded to $1,300.37$ and $1,156.10 \mathrm{~kg} \mathrm{ha}$ 1, 795.05 and $326.95 \mathrm{~kg} \mathrm{ha}^{-1}$ of $\mathrm{Ca}$ in the total 
biomass, remaining biomass, leaves, and stems, respectively. In the largest population of plants and $\mathrm{N}$ dose (20 g per plant), $147.3 \mathrm{~kg} \mathrm{ha}^{-1}$ of $\mathrm{Ca}(11.3 \%)$ were exported by the seedlings and
$144.2 \mathrm{~kg} \mathrm{ha}^{-1}$ by the fruits (11.1\%); and remained in the area $77.59 \%\left(1.008 .91 \mathrm{~kg} \mathrm{ha}^{-1}\right)$ of all $\mathrm{Ca}$ accumulated by pineapple.
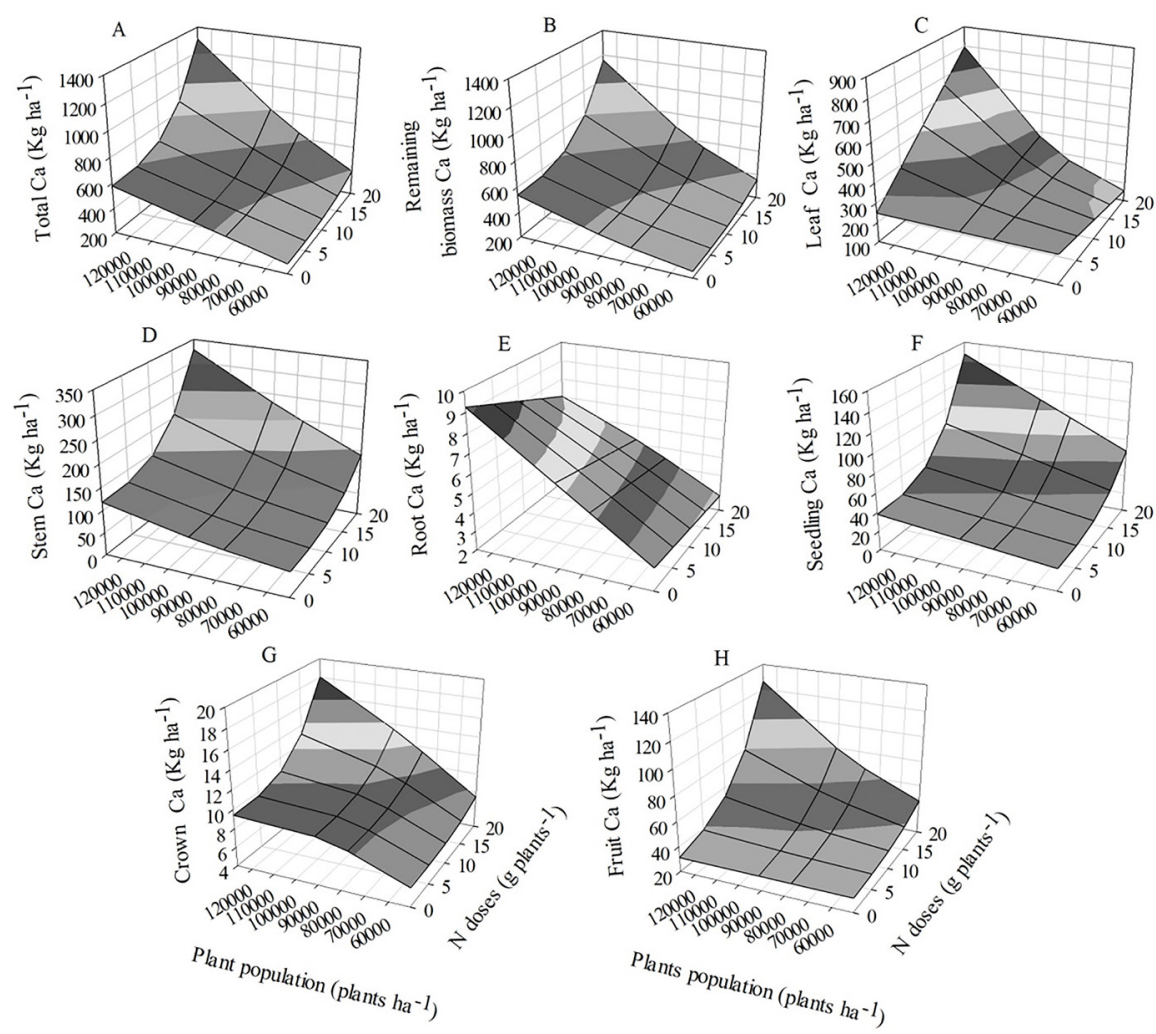

Figure 5. Total Ca accumulation (A), in the remaining biomass (B), leaf (C), stem (D), root (E), seedlings $(F)$, crown $(G)$ and fruit $(H)$ of the 'Vitória' pineapple as a function of $N$ doses and population densities.

Table 5. Equations and determination coefficients for the total Ca accumulation in the remaining biomass (Rem.), Leaf, stem, root, seedlings, crown and fruit of the pineapple.

\begin{tabular}{llc}
\hline Variable & Equation & $R^{2}$ \\
\hline Total & $\hat{Y}=76.32+0.0041 \mathrm{D}+0.000000000005\left(\mathrm{~N}^{3} \mathrm{D}^{2}\right)$ & 0.82 \\
Rem. & $\hat{Y}=31.04+0.0042 \mathrm{D}+0.000000000004\left(\mathrm{~N}^{3} \mathrm{D}^{2}\right)$ & 0.82 \\
Leaf & $\hat{Y}=294.74-0.0004(\mathrm{ND})+0.000000004\left(\mathrm{ND}^{2}\right)$ & 0.75 \\
Stem & $\hat{Y}=38.74+0.000000005 \mathrm{D}^{2}+0.0000002\left(\mathrm{~N}^{3} \mathrm{D}\right)$ & 0.87 \\
Root & $\hat{Y}=1.89+0.0000000004 \mathrm{D}^{2}+0.0000000001\left(\mathrm{ND}^{2}\right)-0.00000000002\left(\mathrm{~N}^{2} \mathrm{D}^{2}\right)+0.0000000000007\left(\mathrm{~N}^{3} \mathrm{D}^{2}\right)$ & 0.78 \\
Seedling & $\hat{Y}=17.54+0.0002(\mathrm{ND})-0.00002\left(\mathrm{~N}^{2} \mathrm{D}\right)+0.000001\left(\mathrm{~N}^{3} \mathrm{D}\right)$ & 0.75 \\
Crown & $\hat{Y}=3.22+0.00006 \mathrm{D}+0.00000000000007\left(\mathrm{~N}^{3} \mathrm{D}^{2}\right)$ & 0.78 \\
Fruit & $\hat{Y}=43.91-0.5210 \mathrm{~N}^{2}+0.0272 \mathrm{~N}^{3}+0.00002(\mathrm{ND})$ & 0.77 \\
\hline In the equation: $\mathrm{N}=$ doses of $\mathrm{N}$ and $\mathrm{D}=$ density of plants; $\mathrm{R} 2=$ determination coefficient.
\end{tabular}

All compartments of the pineapple, except for the root, accumulated more significant amounts of $\mathrm{Mg}$ with use of $20 \mathrm{~g}$ of $\mathrm{N}$ per plant in the most abundant plant population (Figure 6 and Table 6). The accumulation of $\mathrm{Mg}$ in total biomass, remaining biomass, leaves and stem was $380.58 ; 360.71 ; 220.28$ and $58.88 \mathrm{~kg}$ $\mathrm{ha}^{-1}$, respectively. The seedlings, the crown and the fruit accumulated, respectively, 66,56; 7.83 and $37.87 \mathrm{~kg} \mathrm{ha}^{-1}$ of $\mathrm{Mg}$, implying on the export of $19.5 \%\left(112.30 \mathrm{~kg} \mathrm{ha}^{-1}\right)$ of $\mathrm{Mg}$ absorbed by pineapple.

The largest accumulations of $S$ in pineapple and its compartments, except root and leaves, occurred with the use of $20 \mathrm{~g}$ per plant of $\mathrm{N}$ in the highest population density (Figure 7 and Table 7). The maximum accumulation of $S$ in total biomass, the remaining biomass and stalk was 298.97; 253.89; $105.77 \mathrm{~kg} \mathrm{ha}^{-1}$, respectively. The leaves accumulated $127.50 \mathrm{~kg} \mathrm{ha}^{-1}$ with 

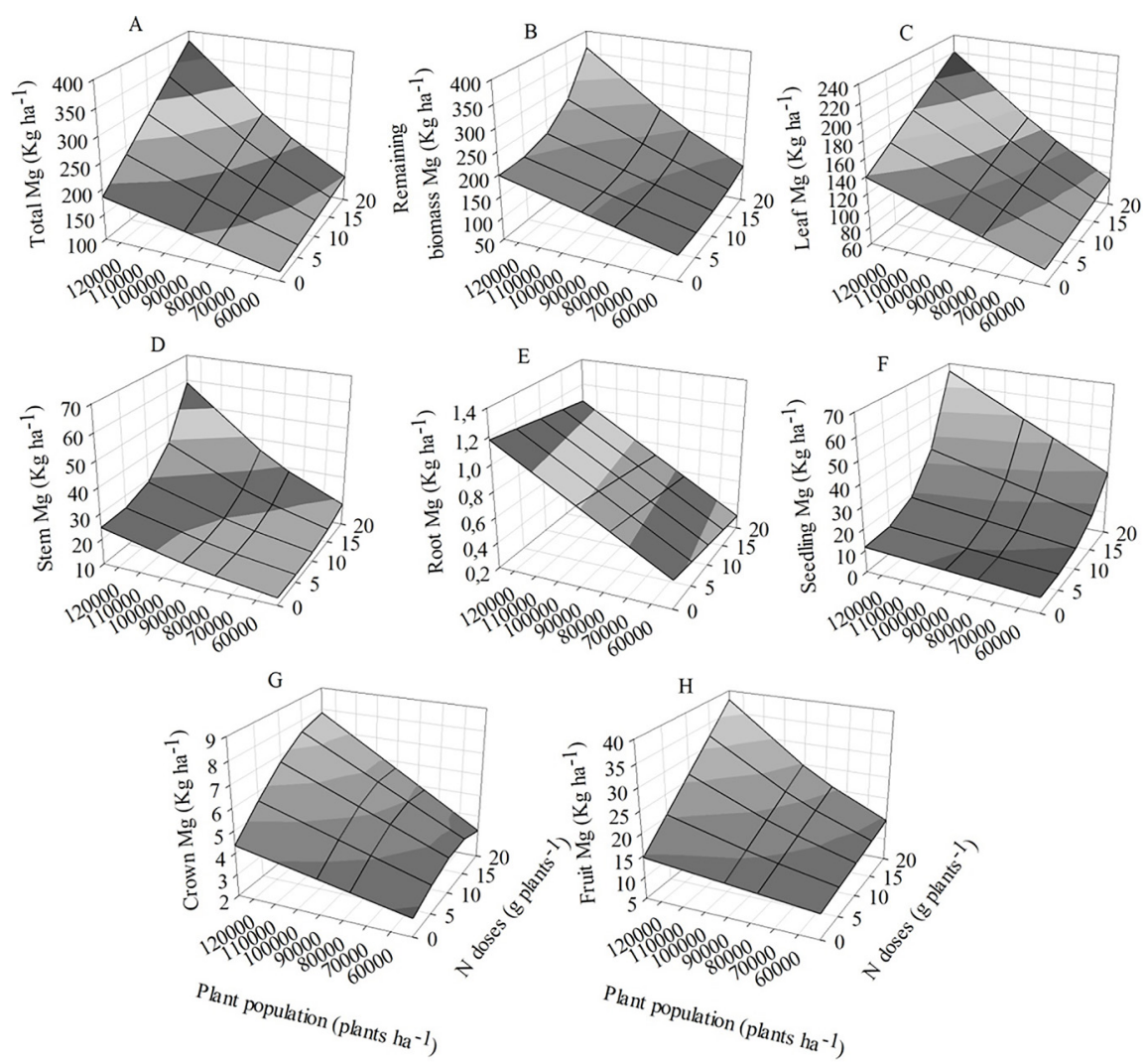

Figure 6. Total Mg accumulation (A), in the remaining biomass (B), leaf (C), stem (D), root (E), seedlings (F), crown (G) and fruit $(H)$ of the 'Vitória' pineapple as a function of $N$ doses and population densities.

Table 6. Equations and determination coefficients for the total Mg accumulation in the remaining biomass (Rem.), Leaf, stem, root, seedlings, crown and fruit of the pineapple.

\begin{tabular}{|c|c|c|}
\hline Variable & Equation & $\mathrm{R}^{2}$ \\
\hline Total & $\hat{Y}=124.43+0.000000005\left(N D^{2}\right)-0.0000000006\left(N^{2} D^{2}\right)+0.00000000002\left(N^{3} D^{2}\right)$ & 0.83 \\
\hline Rem. & $\hat{Y}=110.93+0.000000004\left(N D^{2}\right)-0.0000000006\left(N^{2} D^{2}\right)+0.00000000002\left(N^{3} D^{2}\right)$ & 0.84 \\
\hline Leaf & $\hat{Y}=84.88+0.000000004\left(N^{2}\right)-0.0000000005\left(N^{2} D^{2}\right)+0.00000000001\left(N^{3} D^{2}\right)$ & 0.84 \\
\hline Stem & $\hat{Y}=8.46+0.000000001 D^{2}+0.00000002\left(N^{3} D\right)$ & 0.72 \\
\hline Root & $\hat{Y}=-0.15+0.00002 \mathrm{D}-0.00000008\left(\mathrm{~N}^{2} \mathrm{D}\right)+0.000000004\left(\mathrm{~N}^{3} \mathrm{D}\right)$ & 0.77 \\
\hline Seedling & $\hat{Y}=4.93+0.00008(N D)-0.00001\left(N^{2} D\right)+0.0000004\left(N^{3} D\right)$ & 0.83 \\
\hline \multirow[t]{2}{*}{ Crown } & $\hat{Y}=-5.07+0.45 N+0.0002 D-0.000000001\left(D^{2}\right)-0.00002(N D)+0.0000000002\left(N D^{2}\right)+$ & \multirow{2}{*}{0.68} \\
\hline & $0.000001\left(N^{2} D\right)-0.00000000001\left(N^{2} D^{2}\right)-0.00000004\left(N^{3} D\right)+0.0000000000004\left(N^{3} D^{2}\right)$ & \\
\hline \multirow[t]{2}{*}{ Fruit } & $\hat{Y}=-14.51+1.03 N+0.0007$ D-0.000000003 (DN2)-0.00005 (ND)+0.0000000005 (ND2)- & \multirow{2}{*}{0.64} \\
\hline & $0.00000000002\left(\mathrm{~N}^{2} \mathrm{D}^{2}\right)+0.00000008\left(\mathrm{~N}^{3} \mathrm{D}\right)$ & \\
\hline
\end{tabular}

use of $15 \mathrm{~g}$ per plant of $\mathrm{N}$ in the largest plant population. The maximum accumulation of $S$ in seedlings, crown, and fruits, respectively, was 45.16; 5.11 and $30.38 \mathrm{~kg} \mathrm{ha}^{-1}$.

Considering the largest population of plants and dose of $\mathrm{N}$, the export of $\mathrm{S}$ by fruits was of the order of $35.49 \mathrm{~kg} \mathrm{ha}^{-1}$, which represents $11.9 \%$ of the total accumulated, and the seedlings exported $45.16 \mathrm{~kg} \mathrm{ha}^{-1}(15.1 \%)$. The remaining in the area $218.32 \mathrm{~kg} \mathrm{ha}^{-1}$, corresponding to $73.0 \%$.
Pegoraro et al. (2014b) reported that the 'Vitória' pineapple cultivated with a population density of 51,280 plants ha-1 and fertilized with $15 \mathrm{~g}$ per plant of $\mathrm{N}$ accumulated in the total biomass $451.71 \mathrm{~kg} \mathrm{ha}^{-1}$ of $\mathrm{N}, 107.26 \mathrm{~kg} \mathrm{ha}^{-1}$ of $\mathrm{P}, 898.32 \mathrm{~kg}$ $\mathrm{ha}^{-1}$ of $\mathrm{K}, 129.17 \mathrm{~kg} \mathrm{ha}^{-1}$ of $\mathrm{Ca}, 126 \mathrm{~kg} \mathrm{ha}^{-1}$ of $\mathrm{Mg}$ and $134.47 \mathrm{~kg} \mathrm{ha}-1$ of S. Oliveira (2013) described that the 'Pearl' breed pineapple grown with doses of $15 \mathrm{~g}$ per plant of $\mathrm{N}$ and 47,619 plants $\mathrm{ha}^{-1}$ accumulated in the total biomass $763.65 \mathrm{~kg} \mathrm{ha}^{-1}$ 

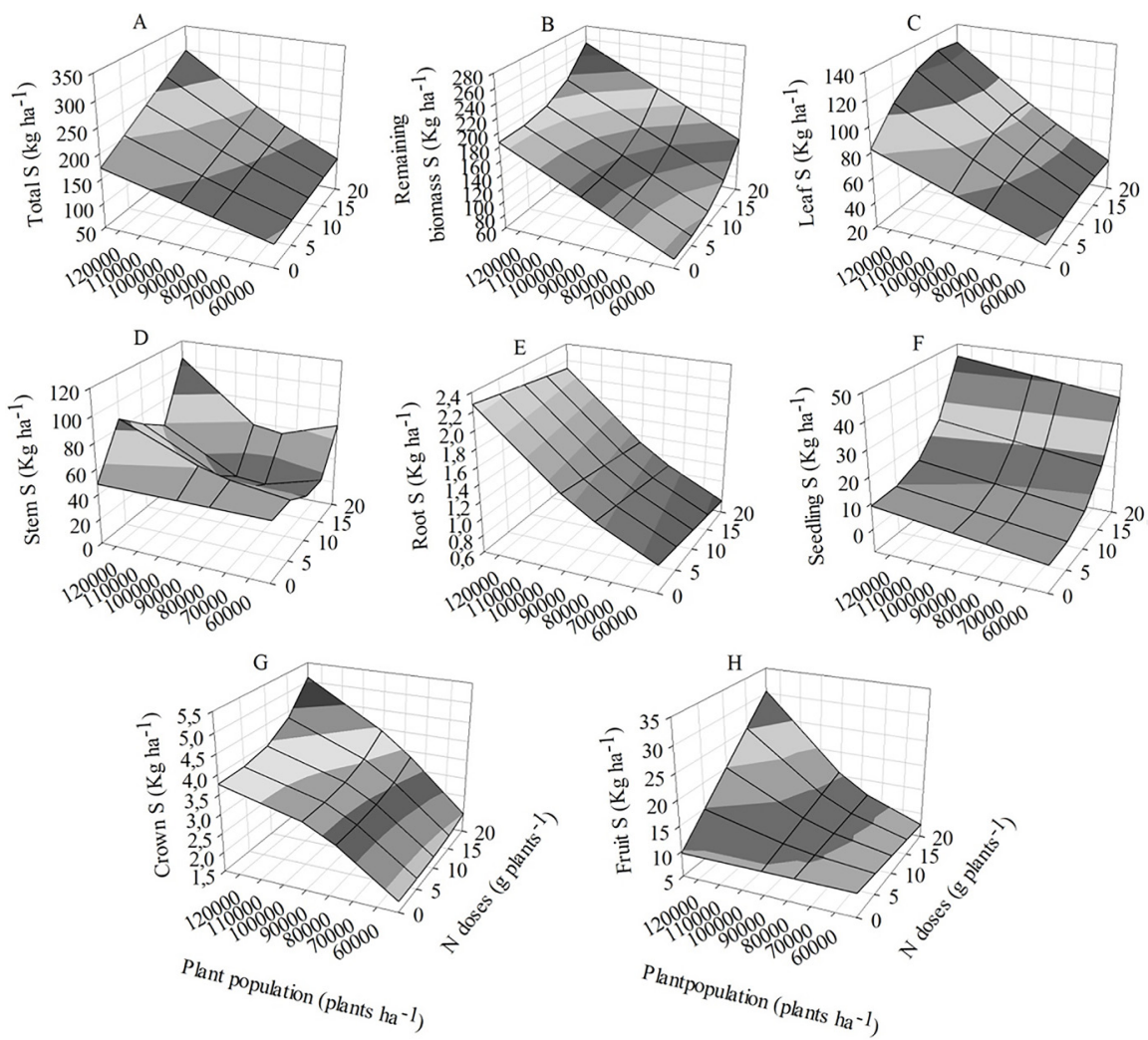

Figure 7. Total $S$ accumulation (A), in the remaining biomass (B), leaf (C), stem (D), root (E), seedlings $(F)$, crown $(\mathrm{G})$ and fruit $(\mathrm{H})$ of the 'Vitória' pineapple as a function of $\mathrm{N}$ doses and population densities.

Table 7. Equations and determination coefficients for the total $S$ accumulation in the remaining biomass (Rem.), Leaf, stem, root, seedlings, crown and fruit of the pineapple.

\begin{tabular}{|c|c|c|}
\hline Variable & Equation & $\mathrm{R}^{2}$ \\
\hline S total & $\hat{Y}=111.72+0.000000003\left(N^{2}\right)-0.00003\left(N^{2} D\right)-0.0000000001\left(N^{2} D^{2}\right)+0.000002\left(N^{3} D\right)$ & 0.75 \\
\hline S Rem. & $\hat{Y}=100.73+0.000000003\left(N^{2}\right)-0.000025\left(N^{2} D\right)-0.0000000001\left(N^{2} D^{2}\right)+0.000001\left(N^{3} D\right)$ & 0.73 \\
\hline S leaf & $\hat{Y}=28.66+0.000000004 D^{2}+0.0000000001\left(N^{2}\right)$ & 0.71 \\
\hline S stem & $\begin{array}{l}\hat{Y}=-103.80+0.0039 D+1.54 N^{2}-0.00000002 D^{2}-0.041 N^{3}-0.0004(N D)+0.000000005\left(N^{2}\right)- \\
0.0000000003\left(N^{2} D^{2}\right)+0.00000000001\left(N^{3} D^{2}\right)\end{array}$ & 0.77 \\
\hline S root & $\hat{Y}=-0.12+0.00002 \mathrm{D}+0.000003(\mathrm{ND})-0.0000004\left(\mathrm{~N}^{2} \mathrm{D}\right)+0.00000001\left(\mathrm{~N}^{3} \mathrm{D}\right)$ & 0.82 \\
\hline S seedling & $\hat{\mathrm{Y}}=3.15+5.82 \mathrm{~N}-0.7861 \mathrm{~N}^{2}+0.030 \mathrm{~N}^{3}$ & 0.81 \\
\hline S crown & $\hat{Y}=0.55+0.00002 \mathrm{D}+0.00000000002\left(\mathrm{ND}^{2}\right)-0.000000000004\left(\mathrm{~N}^{2} \mathrm{D}^{2}\right)+0.0000000000001\left(\mathrm{~N}^{3} \mathrm{D}^{2}\right)$ & 0.70 \\
\hline S fruit & $\hat{Y}=1.54+0.0001 \mathrm{D}+0.00003(\mathrm{ND})-0.000005\left(\mathrm{~N}^{2} \mathrm{D}\right)+0.0000002\left(\mathrm{~N}^{3} \mathrm{D}\right)$ & 0.72 \\
\hline
\end{tabular}

of $\mathrm{N} ; 14.04 \mathrm{~kg} \mathrm{ha}^{-1}$ of $\mathrm{P} ; 795.72 \mathrm{~kg} \mathrm{ha}^{-1}$ of $\mathrm{K} ; 397.84$ $\mathrm{kg} \mathrm{ha}^{-1}$ of $\mathrm{Ca}, 49.80 \mathrm{~kg} \mathrm{ha}^{-1}$ of $\mathrm{Mg}$ and $48.90 \mathrm{~kg}$ $\mathrm{ha}^{-1}$ of S. From these data we shall infere, that the accumulation of nutrients in pineapple varies, among other factors, with the genetic material and with the adopted management (fertilization and plant density).

The decreasing order of macronutrient accumulation in 'Vitória' pineapple was as follows: $\mathrm{K}>\mathrm{N}>\mathrm{Ca}>\mathrm{P}>\mathrm{Mg}>\mathrm{S}$. Pegoraro et al. (2014a) reported as follows: $K>N>C a>M g>P$. In the cultivar Pérola, Amaral et al. (2014) depicted that the order of accumulation in the plant was $\mathrm{K}>\mathrm{N}>\mathrm{Ca}>\mathrm{P}>\mathrm{Mg}$, and according to Oliveira (2013), K>N>Ca> Mg> S>P. This variation in nutritional demand is due to management, soil type, nutrient availability, climatic conditions and cultivar (Guarçoni M. \& Ventura, 2011). However, in the present study and all the cited studies, $K$ and $\mathrm{N}$ are always, and necessarily in that order, the most absorbed by the plant.

In this study, it was observed a higher 
absorption ( $\mathrm{K}$ accumulation) by 'Vitória' pineapple compared to N. However, the current fertilization recommendation for Minas Gerais recommends the use of higher $\mathrm{N}$ rates compared to $K$, indicating the need for adequacy of the $N$ and $K$ doses recommended for the pineapple crop.

The 'Vitoria' pineapple accumulated higher amounts of macronutrients in the leaves followed by the seedlings, stem, fruit, crown, and root. The leaves and stem accumulated larger amounts of biomass. The fruits exported nutrients in the following order: $\mathrm{K}>\mathrm{Ca}>\mathrm{N}>\mathrm{P}>\mathrm{Mg}>\mathrm{S}$, as for the offspring: $\mathrm{K}>\mathrm{N}>\mathrm{Ca}>\mathrm{P}>\mathrm{Mg}>\mathrm{S}$. It is noticeable that the nutrient demand for the fruit and seedlings differs with respect to $\mathrm{Ca}$ and $\mathrm{N}$, the first being more required by the fruit and the second by the seedlings. For efficient management of pineapple fertilization, the nutrient doses provided should consider the amount of nutrient exported and remaining in the remaining biomass, once the export increases, the use of higher doses is necessary.

\section{Conclusions}

The dose of $20 \mathrm{~g}$ per plant of $\mathrm{N}$ combined with the population of 126,984 plants $\mathrm{ha}^{-1}$ provides more significant accumulation of biomass and macronutrients in 'Vitória' pineapple.

The 'Vitoria' pineapple accumulates in the plants, and exports the following order of macronutrients, via fruits and seedlings: $K>N>$ $\mathrm{Ca}>\mathrm{P}>\mathrm{Mg}>\mathrm{S}$.

The leaves and the stem are the organs of the pineapple with greater accumulation of macronutrients.

\section{Acknowledgments}

The authors thank the Foundation for Research Support of Minas Gerais (FAPEMIG), National Council for Scientific and Technological Development (CNPq) and Pro-Rectory Research of Federal University de Minas Gerais (PRPqUFMG) for financial and scholarship support. We also thank the CNPq for the Research Productivity Grant to the second and fourth authors.

\section{References}

Amaral, U.D., Maia, V.M., Pegoraro, R.F., Kondo, M.K., Aspiazú, I. 2014. Water dephts and macronutrients accumulation in 'Pérola' pineapple irrigated by drip. RevistaBrasileira de Fruticultura 36: 755-760.

Bataglia O.C.; Furlani A.M.C.; Teixeira J.P.F.; Furlani P. R.; Gallo J.R. Methods of chemical analysis of plants. Campinas: Instituto Agronômico, 1983. 48p. (Boletim, 78)

Caetano, L.C.S., Ventura, J.A., Costa, A.F.S., Guarçoni, R.C. 2013. Effect of fertilization with nitrogen, phosphorus and potassium on growth, yield and fruit quality of pineapple 'Vitoria'. Revista Brasileira de Fruticultura 35: 883-890.

Cardoso, M.M., Pegoraro, R.F., Maia, V.M., Kondo, M.K., Fernandes, L.A. 2013. Growth of pineapple 'vitória' irrigated under different population densities, sources and doses of nitrogen. Revista Brasileira de Fruticultura 35: 769-781.

Franco, L.R.L., Maia, V.M., Lopes, O.P., Franco, W.T.N., Santos, S.R. 2014. Growth, production and quality of 'Pérola' pineapple under different irrigation depth. Revista Caatinga 27: 132-140.

Guarçoni, M.A., Ventura, J.A. 2011. Nitrogen, P and $\mathrm{K}$ fertilization and the development, yield and fruit quality of pineapple 'gold' (MD-2). Revista Brasileira de Ciência do Solo 35: 13671376.

Marques, L.S., Andreotti, M., Buzetti, S., Isepon, J.S. 2011. Productivity and quality of pineapple cv. Smooth Cayenne, cultivated with nitrogen doses and splitting application in Guaraçaí-SP. RevistaBrasileira de Fruticultura33: 1004-1014.

Oliveira, F.S.2013. Growth, yield and nutrient uptake by 'Pérola'pineapple. 81 f. (Master Degree Dissertation) - Universidade Estadual de Montes Claros, Janaúba, Brasil.

Pegoraro, R.F., Souza, B.A. M.D., Maia, V.M., Silva, D.F.D., Medeiros, A.C., Sampaio, R.A. 2014a. Macronutrient uptake, accumulation and export by the irrigated 'Vitória' pineapple plant. Revista Brasileira de Ciência do Solo 38: 896-904.

Pegoraro, R.F., Souza, B.A.M.D., Maia, V.M., Amaral, U.D. Pereira, M.C.T. 2014b. Growth and production of irrigated 'Vitória' pineapple grown in semi-arid conditions. Revista Brasileira de Ciência do Solo 36: 693-703.

Souza, M.; Guimarães, P.T.G.; Carvalho, J.G.; Fragoas, J.C. 1999. Abacaxizeiro. In: Ribeiro, A.C.; Guimarães, P.T.G.; Alvarez V., V.H. (ed.) Recommendations for the use of correctives and fertilizers in Minas Gerais. 5th Approach. Viçosa: Comissão de Fertilidade do Solo do Estado de Minas Gerais. p. 216.

Santana, L.L.A., Reinhardt, D.H., Cunha, G.A.P., Caldas, R.C. 2001. High planting density for 
the smooth cayenne pineapple crop, grown under rainfed conditions. Revista Brasileira de Fruticultura 23: 353-358.

Silva, A.P., Alvarez, V.H., Souza, A.P., Neves, J.C.L., Novais, R.F., Dantas, J.P. 2009. System of recommendation of fertilizers and correctives for the pineapple culture - fertcalc- pineapple. Revista Brasileira de Ciência do Solo 33: 12691280.

Silva, A.L.P., Silva, A.P., Souza, A.P., Santos, D., Silva, S.D.M., Silva, V.B. 2012. Response of 'Vitória' pineapple to nitrogen in coastal tablelands in Paraiba. Revista Brasileira de Ciência do Solo 36: 447-456.

Silva, F.C. 2009.Manual ofchemicalanalyzesofsoils, plantsandfertilizers. Brasilia: Informações Tecnológicas, EMBRAPA. 2. Ed.: Brasília, Brasil. 627 p.

Taiz, L., Zeiger, E. 2013. Fisiologia vegetal. 5. ed. Artmed, Porto Alegre, Brasil. 918 p.

Vilela, G.B., Pegoraro, R.F., Maia, V.M. 2015. Predicting the production of 'Vitória' pineapple from phytotechnical and nutritional characteristics. Revista Ciência Agronômica 46: 724-732. 